\title{
ANALYSIS OF THE RELATIONSHIP OF THE LEARNING VIDEO WITH STUDENTS 'UNDERSTANDING OF LEARNING MATERIALS
}

\author{
${ }^{1}$ Yulyani Arifin, ${ }^{2}$ Diana Syarifah Permai, ${ }^{3}$ Dicky Hida Syahchari, ${ }^{4}$ A. Raharto Chondrobimo \\ ${ }^{1}$ Computer Science Department, School of Computer Science, \\ Bina Nusantara University, Jakarta, Indonesia 11480 \\ ${ }^{2}$ Statistics Department, School of Computer Science, \\ Bina Nusantara University, Jakarta, Indonesia11480 \\ ${ }^{3}$ Management Department, Binus Business School, \\ Bina Nusantara University, Jakarta, Indonesia 11480 \\ ${ }^{4}$ Information System Department, School of Information System, \\ Bina Nusantara University, Jakarta,Indonesia 11480 \\ 1yulyaniarifin@binus.ac.id
}

Received: January $19^{\text {th }}, 2021 /$ Revised: February $18^{\text {th }}$ 2021/ Accepted: March $12^{\text {th }}, 2021$

\begin{abstract}
The aim of the study was to examine the relationship between the relationship between instructional videos and students' understanding of the learning material. Researchers create digital learning materials through video material (VBL), especially math in RPTRA. The researchers used correlation analysis to examine the relationship between the learning material in video form and the level of understanding of the students in the material. The method used by the researcher was to experiment with elementarylevel children from various primary schools. Then, based on the experimental results, the correlation analysis test was performed to see the relationship between the student's understanding and the learning material through video. From the results of the assessment, it can be seen that the video material can help the understanding of the students and can also increase themotivation of the students in learning mathematics. Therefore, video learning can help students understand mathematics and help teachers teach mathematics in a more interesting way.
\end{abstract}

Keywords: Education, Mathematics, RPTRA, VBL

\section{Introduction}

RPTRA is a child-friendly integrated public space provided by the government of DKI Jakarta since 2016. The purpose of conducting this RPTRA is as a forum for interaction between residents around RPTRA. According to Prakoso and Dewi's research, RPTRA users are generally the ones most used bychildren to play and learn (Prakoso \& Dewi, 2017). RPTRA is one of the appropriate places for childrento interact with the environment, children can play, have fun and receive education (Herlina \& Nadiroh,2018) For example, RPTRA Maya Asri 13, children of primary level receive direct guidance about thelesson. free of professors and lecturers from various places of education. One of the lessons taught is mathematics. In teaching mathematics, you must be able to improve higher order thinking skills and understanding of mathematics (Kaya \& Aydin, 2016). Therefore, a way is needed to teach mathematicsto elementary school children and make them understand.

Of course, to attract the attention of children to learn, we need new ways, especially to study subjects such as mathematics. Children at this elementary level are the generation after Generation $Z$ or better known as digital natives. Generation $\mathrm{Z}$ has a more effective way of learning through images with the use of technology (Rothman, 2016.). Especially for generation after generation Z prefer visual things 
like videos. From the research conducted by Lin et al, digital learning has a positive effect, especially by increasing learning motivation compared to the previous way (Lin, Chen, \& Liu, 2017).

For this reason, the researcher proposes to create digital learning materials through video material. The researchers used correlation analysis to examine the relationship between the learning material in video form and the level of understanding of the students in the material. The method used by the researcher was to experiment with elementary-level children from various primary schools. Then, based on the experimental results, the correlation analysis test was performed to see the relationship between the student's understanding and the learning material through video. From the results of the analysis, it can be concluded that the children like the learning materials through video and better understand the material transmitted through the video material.

\section{Literature review}

Saleh et al have conducted mathematics-related research, which improves students' ability to learn mathematics through the teaching of mathematics through the use of real-life examples (Saleh, Charitas,Prahmana, \& Isa, 2018). But of course, if the students want to repeat it again, it will take the teacher's effort to repeat it again. This is time consuming and therefore ineffective in learning. However, if this learning method is applied in video material, it will be more beneficial and can also be used by students with disabilities.

Learning English in children through educational videos has a positive effect by increasing vocabularyin English (Celis Nova, Isabel Onatra Chavarro, \& Tatiana Zubieta Córdoba, 2017). Of course, this canalso be applied to mathematics subjects.

\section{Methodology}

The methodology in this research is as follows:

1. Problem analysis

Research and related material that can be used as math learning material to be turned into video material is discussed at this stage.

2. Make video material

Realization of video material based on mathematics subjects for children in the fourth grade of primary school. In the video material, examples are given that are closely related to children's everyday life and add animation to attract children's attention.

3. Experiment

The experimental stage consisted of the children testing 1 video material presented with a specific topic. The children were then asked to do tasks according to the given theme. After that, she was asked to fill out an evaluation questionnaire. The experiment was tested on primary school children located in Jakarta. The number of respondents who participated was 20 people.

4. Tau Kendall correlation test.

The variables measured were the variables of student comprehension through instructional videos, student evaluation of the video under study, comparison of video material that was easier to understand than textbooks, and ease of repeating lessons. with videos. The correlation tested was to determine the relationship between the student's understanding of the given video learning material. This method was chosen because the data we have is ordinal data..

\section{Results and Discussion}

The video learning materials are developed according to the math textbooks (Kemendikbud). In thefollowing figure you can see an example of capturing video material. (Fig 1-2) 


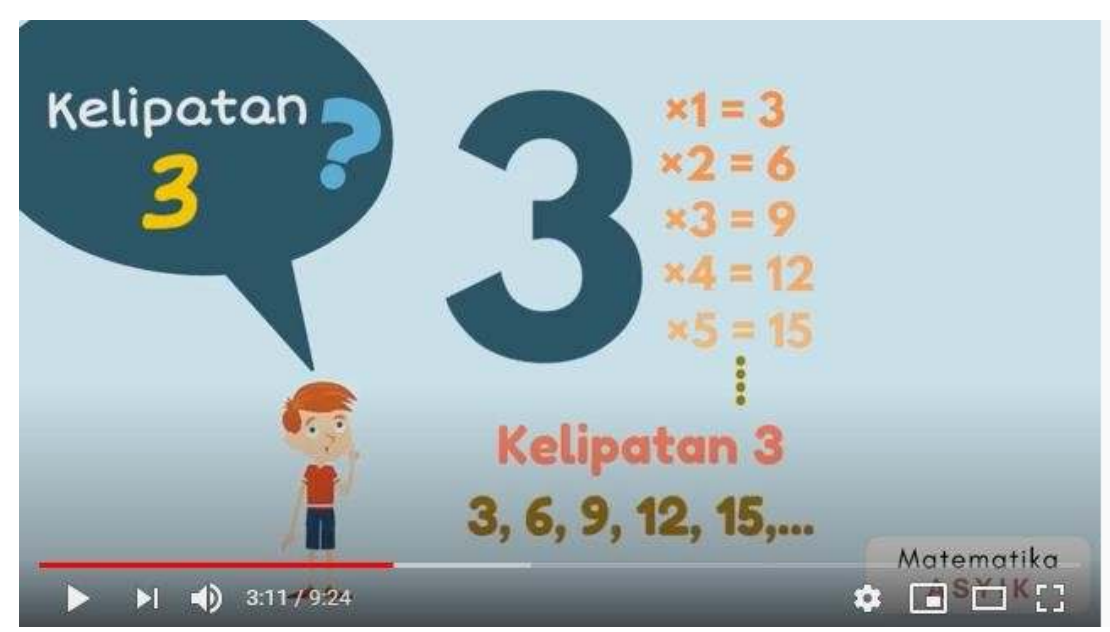

Figure 1 Material Multiples of numbers

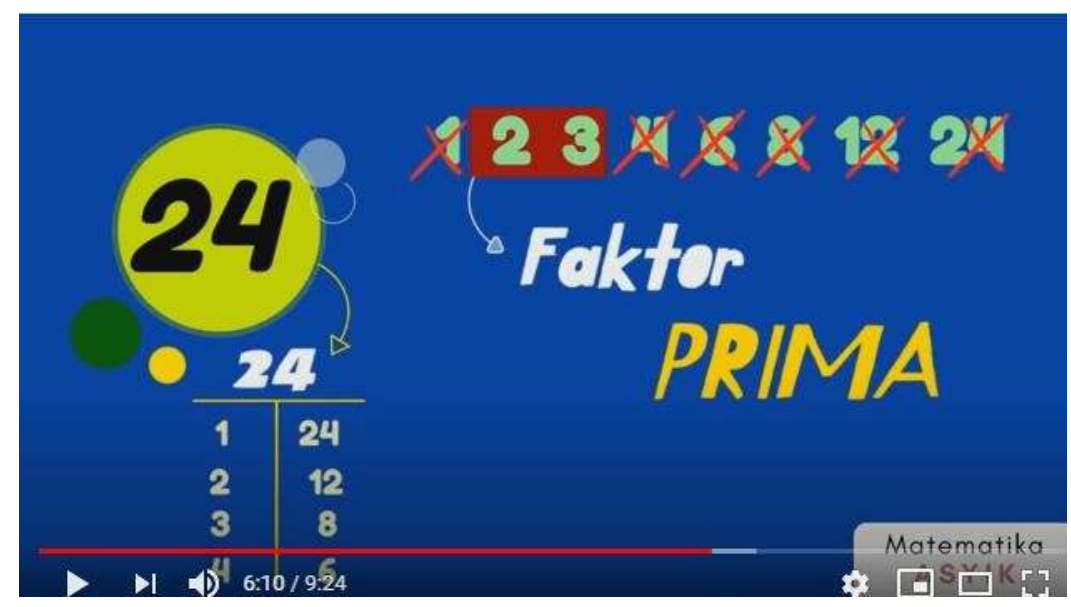

Figure 2 Prime factors

\section{Correlation test results}

The research was carried out by asking elementary school students in grades 4-6 to learn about FPB andKPK using video learning media. In addition, students work on practice questions and complete the learning assessment form. The following is a data analysis of the contents of the learning assessment form that has been carried out by various samples of primary school students. 


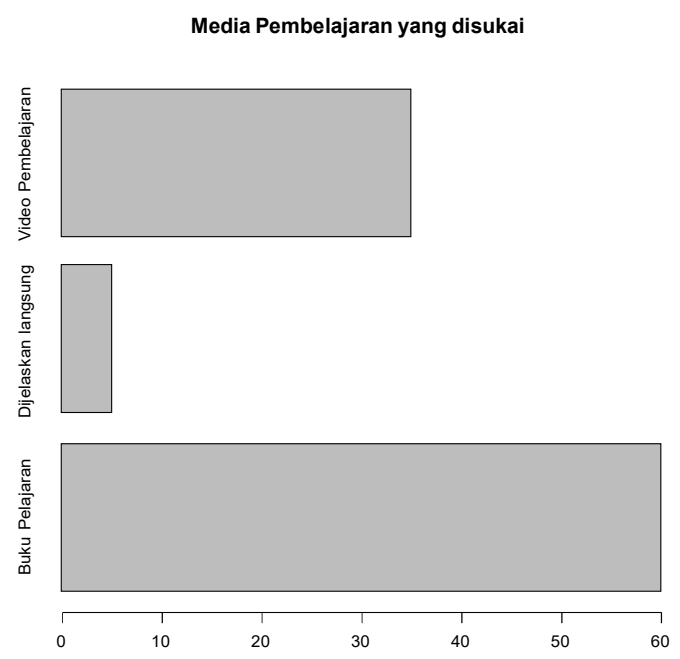

Figure 3 The graphic of the preferred learning media

Based on the image above regarding preferred learning media. This figure (Fig. 3) shows that $60 \%$ of students prefer to learn using textbooks, while $35 \%$ of students who like to learn through video and 5\%prefer to have it explained to them directly. This shows that textbooks still have an important role in learning, but videos can be used as an alternative to learning.

Below are the results of the evaluation of the learning videos that have been made and studied by the students

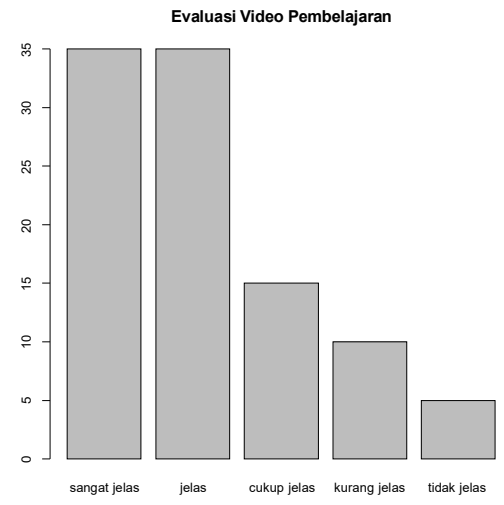

Figure 4 The graphics of the video based learning evaluation

The picture above (Fig. 4) shows that $70 \%$ of the students stated that the learning video that had been made was very clear and clear in the delivery of FPB and KPK learning materials. Meanwhile, $15 \%$ ofthe students stated that the video was clear enough and the remaining $15 \%$ said that the video was not clear. This shows that there is still a need to improve how-to video creation. Because there are still students who do not understand the didactic material of the videos that the students have made and studied. Therefore, more research can be done on the improvement aspects of instructional videos, so that videos can be made that are more interactive and help students to understand the subject. 
In addition, a correlation analysis of the students' comprehension variables was performed through thevideo lessons, the student evaluations of the videos under study, the comparison of video material easierto understand than textbooks and the ease of repeating video lessons. The correlation analysis method used is the Tau Kendall correlation. This is because the data obtained has an ordinal measurement scale.In general, the hypothesis used in the correlation test is

H0: $\rho=0$ (There is no correlation between the two variables)

H0: $\rho \neq 0$ (There is a correlation between the two variables)

The following are the results of the correlation analysis of these four variables.

1. Correlation of student understanding through instructional videos with student assessments of the videos being studied

From the data that have been processed using the Tau Kendall correlation, the following results are obtained

> cor.test(math\$pemahaman, math\$evaluasi, method="kendall")

Kendall's rank correlation tau

data: math\$pemahaman and math\$evaluasi

$z=3.44, p$-value $=0.0005817$

alternative hypothesis: true tau is not equal to 0

sample estimates:

tau

0.6643638

The value of $\alpha=0.05$ and the $\mathrm{p}$-value $=0.0005817$ then the $\mathrm{p}$-value $<\alpha$ to reject $\mathrm{H} 0$. Then it can be concluded that there is a correlation between the two variables. This shows that the learning videos that students have watched have a bearing on students' understanding of the video material.This means that if the video made is interactive, interesting and understandable, the students will better understand the material through the video.

2. The correlation between the ease of repeating video lessons with student evaluations of the videos being studied. The following is the result of the Tau Kendall correlation analysis.

> cor.test (math\$kemudahan, math\$evaluasi, method="kendall")

Kendall's rank correlation tau

data: math\$kemudahan and math\$evaluasi

$z=3.3713, p$-value $=0.0007481$

alternative hypothesis: true tau is not equal to 0

sample estimates:

tau

0.6527778

Based on the above result, it can be concluded that there is a correlation between the ease of repeating lessons with the students' evaluations of the instructional videos. This is obtained because the $\mathrm{p}$-value is 0.0007481 , so the $\mathrm{p}$-value is $<\alpha$, with a value of $\alpha=0.05$. This shows that the videos students learnwill make it easier to repeat the lessons. This means that the video made must be able to help students understand the lesson so that they can repeat the video and better understand the topic.

\section{Conclusion}

From the results of the assessment, it can be seen that the video material can help the understanding ofthe students and can also increase the motivation of the students in learning mathematics. Therefore, video learning can help students understand mathematics and help teachers 
teach mathematics in a moreinteresting way. Current research has not reached the skill level of the students if it has increased usinglearning material in the form of video. For further investigation, preand post-test measurements will be carried out on students to find out more clearly if there is an effect on abilities.

\section{References}

Celis Nova, J., Isabel Onatra Chavarro, C., \& Tatiana Zubieta Córdoba, A. (2017). Educational videos: a didactic tool for strengthening English vocabulary through the development of affective learning in kids 1 Videos educativos: una herramienta didáctica para el fortalecimiento del vocabulario en inglés mediante el desarrollo del aprendizaje afectivo en niños, 14(14), 6887.

Herlina, N., \& Nadiroh, N. (2018). Peran Strategis Ruang Publik Terpadu Ramah Anak (Rptra) Dalam Rangka Pemenuhan Hak Anak Terhadap Lingkungan. JPUD - Jurnal Pendidikan Usia Dini, 12(1), 104-117. https://doi.org/10.21009//jpud.121.09

Kaya, D., \& Aydin, H. (2016). Elementary mathematics teachers' perceptions and lived experiences on mathematical communication. Eurasia Journal of Mathematics, Science and Technology Education, 12(6), 1619-1629. https://doi.org/10.12973/eurasia.2014.1203a

Lin, M. H., Chen, H. C., \& Liu, K. S. (2017). A study of the effects of digital learning on learning motivation and learning outcome. Eurasia Journal of Mathematics, Science and Technology Education, 13(7), 3553-3564. https://doi.org/10.12973/eurasia.2017.00744a

Prakoso, S., \& Dewi, J. (2017). Child-friendly integrated public spaces (RPTRA): Uses and sense of attachment S. Iopscience.Iop.Org, 8(February 2018), 68-74. https://doi.org/doi:10.1088/17551315/126/1/012199

Rothman, D. (n.d.). 2016_tzunami generation z.pdf.

Saleh, M., Charitas, R., Prahmana, I., \& Isa, M. (2018). Improving the Reasoning Ability of Elementary School Student Through the Indonesian Realistic. Journal on Mathematics Education, 9(1), 41-54. 